\title{
Use of diagnostic modalities in the treatment of perianal fistula: A retrospective cohort study of 307 patients
}

\author{
Perianal fistül tedavisinde tanısal yöntemlerin kullanımı: 307 hastanın retrospektif kohort çalışması
}

\author{
Abdullah Şişik ${ }^{1}$, Ali Kılıç ${ }^{1}$
}

\section{Abstract}

Aim: Deciding on the type of fistula and deciding on the most appropriate type of surgery is still a challenge for anal fistula disease. In this study, we aimed to evaluate whether magnetic resonance imaging (MRI), endoscopic examination and co-administration of both in preoperative preparations of anal fistulas are beneficial in this respect.

Methods: The study was retrospectively performed in patients treated surgically for perianal fistula between 2008 and 2017. The data of 307 patients operated for anal fistulas were reviewed with hospital records. Patients were grouped under the headings of preoperative MRI and non-MRI, endoscopic and non-endoscopic examination, and both performed and non-performed. The demographic data (age, sex), fistula type (simple or complicated), presence or absence of seton and the type of surgery were recorded. These parameters were compared with the groups.

Results: In the preoperative evaluation, $162(53 \%)$ patients had MRI, 83 (27\%) patients had endoscopic examination and $60(20 \%)$ patients had both. There was a statistically significant correlation between the presence of preoperative MRI and the need for seton placement ( $p<0.05$ for all). Preoperative MRI, preoperative endoscopy and preoperative both modalities groups didn't show statistically significant correlation with patient's demographic data, fistula type and surgical method ( $\mathrm{p}>0.05$ for all).

Conclusion: Preoperative modalities such as MRI and endoscopy are not sufficient in determining the type of fistula in an anal fistula and determining the surgical method to be applied. We believe that combining these studies with perioperative examination may be helpful in obtaining more effective results. Also, performing MRI preoperatively may help surgeons for decision of seton placement.

Key words: Perianal fistula, preoperative evaluation, fistula type, seton

Özet

Amaç: Anal fistül hastalığında fistül tipine karar vermek ve en uygun ameliyat tipine karar vermek ileri tetkiklerin kullanılmasına karşın halen içerisinde zorluklar barındırmaktadır. Bu çalışmada, anal fistül hastalarının ameliyat öncesi hazırlıklarında manyetik rezonans görüntüleme (MRG), endoskopik inceleme ve her ikisinin birlikte uygulanmasının bu konuda yararlı olup olmadığını değerlendirmeyi amaçladık.

Yöntemler: Çalışma 2008-2017 yılları arasında perianal fistül nedeniyle cerrahi tedavi uygulanan hastalarda retrospektif olarak yapıldı. Anal fistül nedeniyle ameliyat edilen 307 hastanın verileri hastane kayıtları ile gözden geçirildi. Hastalar ameliyat öncesi MRG yapılan ve yapılmayanlar, endoskopik inceleme yapılan ve yapılmayanlar ve her ikisi yapılan ve yapılmayanlar başlıkları altında gruplandırıldı. Hastaların demografik verileri (yaş, cinsiyet), fistül tipi (basit veya komplike), seton yerleşiminin olup olmadığı ve uygulanan cerrah tipi kaydedildi. Bu parametreler gruplarla karşılaştırıldı.

Bulgular: Ameliyat öncesi değerlendirmede 162 (\% 53) hastaya MRG, 83 (\% 27) hastaya endoskopik inceleme ve $60(\%$ 20) hastaya da her ikisinin birden yapıldığı saptandı. Ameliyat öncesi MRG varlı̆̆ ile seton yerleştirilme gereksinimi arasında istatistiksel olarak anlamlı korelasyon saptandı $(p<0,05)$. Ameliyat öncesi MRG, ameliyat öncesi endoskopi ve ameliyat öncesi her iki uygulamanın varlığı ile hastaların demografik özellikleri, fistül tipi ve uygulanan cerrahi tipi arasında istatistiksel olarak anlamlı ilişki saptanmadı ( $p>0,05)$. Sonuç: Anal fistül hastalığında fistül tipini saptamada ve uygulanacak cerrahi şekline karar vermede MRG, endoskopi gibi preoperatif modaliteler yeterli olamamaktadır, bu incelemelerin peroperatif muayene ile birleştirilerek değerlendirilmesinin daha etkili sonuç elde etmede faydalı olacağı kanaatindeyiz. Ayrıca preoperatif MRG uygulamasının seton gereksinimi konusunda cerrahlara yardımcı olabileceğini düşünmekteyiz. Anahtar sözcükler: Perianal fistül, preoperative inceleme, fistül tipi, seton
${ }^{1}$ Department of General Surgery, University of Health Sciences, Ümraniye Education and Research Hospital, Istanbul, Turkey.

Ethics Committee Approval: The study wass approved by the local ethical committee. Etik Kurul Onayı: Çalışma lokal etik komite tarafindan onaylanmıştır.

Conflict of Interest: No conflict of interest was declared by the authors.

Çıkar Çatışması: Yazarlar çıkar çatışması bildirmemişlerdir

Financial Disclosure: The authors declared that this study has received no financial support.

Finansal Destek: Yazarlar bu çalışma için finansal destek almadıklarını beyan etmişlerdir.

Geliş Tarihi / Received: 15.03.2018

Kabul Tarihi / Accepted: 11.06.2018

Yayın Tarihi / Published: 20.07.2018

Sorumlu yazar / Corresponding author:

\section{Abdullah Sișik}

Genel Cerrahi Kliniği, Sağlık Bilimleri Üniversitesi, Ümraniye Eğitim ve Araştırma Hastanesi, Elmalıkent Mh. Adem Yavuz Cad. 34766, Istanbul, Turkey.

Tel: 0905062623325

e-mail: abdullahsisik@gmail.com

Copyright $($ ACEM 


\section{Introduction}

Anal fistula is a surgical disease that has been known and investigated for about 2500 years [1]. Although the cause is not known for certain; the crypto-glandular theory is the most accepted hypothesis [2, 3].

Diagnosis of the disease is done by physical examination and some additional examinations may be needed before surgery. Physical examination includes inspection of external orifice of anal fistula and digital rectal examination. The identification of the fistula tract and internal orifice with the anal probe ("stile") during the first examination is controversial [4-6]. Magnetic resonance imaging (MRI) and transanal ultrasonography (USG) are the most frequently used imaging methods. These tests are among the first choices to have knowledge about the complexity besides the diagnosis of the disease. Some studies argue that endoscopy should be performed in differential diagnosis. No study was found about the use of endoscopy (colonoscopy or flexible rectosigmoidoscopy (FRS)) routinely or when necessary, in literature [4, 5]. Another important point is that although several guidelines have been published on the standardization of colonoscopy requests, about $20-50 \%$ of the colonoscopy requests are unnecessary or inconsistent with the guidelines [7-9].

In the light of this knowledge, we tried to analyze the role of preoperative MRI and endoscopy in surgical treatment of anal fistula, in this study.

\section{Materials and Methods}

Patients who were operated on perianal fistula between 2008 and 2017 were included in the study. Information of the patients was received from the hospital records. Patient's demographic data, type of fistula, applied surgical method; presence of preoperative MRI and presence of preoperative endoscopy were recorded. Preoperative MRI and preoperative endoscopy in patient's record was noted as present or absent. The rationale of these modalities was not questioned because the decision about the selection of preoperative techniques depends on the attending surgeon. Fistula type is evaluated as simple or complicated according to Park classification. Superficial and intersphincteric fistulas were considered as simple fistulas, transsphincteric, suprasphincteric and extrasphincteric ones were considered as complex fistulas. The relationship with external sphincter and presence of multiple tracts were evaluated with physical examination, MRI and peroperative physical examination under anesthesia. Therefore the fistula type mentioned in this study was especially a postoperative decision. When patient's records were analyzed it was observed that various surgical methods were applied for treatment. We recorded the patients who were treated with seton placement due to the association of the fistula with the external sphincter.

Patients were grouped according to presence of preoperative MRI, presence of preoperative endoscopy and presence of both MRI and endoscopy. Preoperative modalities were evaluated as endoscopy $+/-$, MRI +/- and both $+/$ - to determine the effect on parameters. These groups were compared each other according to demographic data, fistula type and seton requirement.

Patients operated for anal fistula due to Crohn's disease and patients who were operated for recurrent anal fistula were excluded from the study.

\section{Statistical analysis}

All statistical analyses were performed using IBM SPSS Statistics for Windows, version 20.0 (IBM, Armonk, NY, USA). Variables are expressed as mean \pm standard deviations (SD) or as medians (range) depending on their distribution. Categorical variables were expressed as frequencies and percentages. Normally distributed variables were assessed using a t-test for paired groups. The Chi-square with Yates' correction method was used for comparison of continuous parametric variables. The statistical results were presented with a $95 \%$ confidence interval. The differences were considered statistically significant if the $\mathrm{p}$ value was less than 0.05 .

\section{Results}

After exclusion of 53 patients, 307 patients were included in the study. Five of 53 patients had Crohn's disease and 48 had recurrent anal fistula. Two hundred and forty six $(80.2 \%)$ male and $61(19.8 \%)$ female patients were analyzed. The mean age of the patients was $40.6 \pm 11.2$. Patients mostly had simple fistula $(n=239,77.8 \%)$. Surgical methods applied in the study are listed in table 1 . Seton placement was performed in $32(10.4 \%)$ patients. In preoperative examination MRI was present on $162(53 \%)$ patients, endoscopy was present on 83 (27\%) patients and both of these modalities were present on 60 $(20 \%)$ patients. No significant difference was found when comparing the groups with age and gender ( $p>0.05$ for all). There was no significant effect of preoperative endoscopy, MRI, or both in determining the type of perianal fistula $(p>0.05$ for all). There was a significant relationship between MRI use and seton placement, $81 \%$ of the seton placed patients had MRI preoperatively ( $\mathrm{p}<0.05$ for all) (Table1, Table 2$)$.

In analysis of endoscopy group; no pathology was found in $66(80 \%)$ of the endoscopic examinations. Sixteen patients (19\%) had colonic polyps and histopathological examination of all polyps was benign in nature. Endoscopic examinations showed an internal orifice of fistula in only one patient $(1 \%)$.

Table 1: Operation types performed for anal fistula treatment Operation All/ $\mathrm{n}$ Endoscopy $\mathrm{p}$ MRI $\mathrm{p}$ Both (\%)

\begin{tabular}{lccccccc}
\hline $\begin{array}{l}\text { Fistulotomy }- \\
\text { fistulectomy }\end{array}$ & $\begin{array}{c}225 \\
(73.3)\end{array}$ & 61 & 0.944 & 108 & 0.247 & 42 & 0.344 \\
$\begin{array}{l}\text { Seton } \\
\text { placement }\end{array}$ & 32 & 8 & 0.485 & 26 & 0.001 & 8 & 0.479 \\
Mucosal flep & $8(7.5)$ & & & & & & \\
LIFT & $11(9.7)$ & 4 & $\mathrm{n} / \mathrm{a}$ & 6 & $\mathrm{n} / \mathrm{a}$ & 1 & $\mathrm{n} / \mathrm{a}$ \\
FiLaC & $7(4.6)$ & 1 & $\mathrm{n} / \mathrm{a}$ & 5 & $\mathrm{n} / \mathrm{a}$ & 2 & $\mathrm{n} / \mathrm{a}$ \\
Combined & $27(8.7)$ & 7 & 0.847 & 13 & 0.107 & 5 & 0.912 \\
\hline
\end{tabular}

procedures

Total 307

LIFT: Ligation of intersphincteric fistul tract, FiLAC: Fistula laser coagulation, n/a: not applicable

\section{Discussion}

Anal fistula is defined as the pathway connecting two distinct epithelial surfaces formed between the anal canal and perianal skin texture $[5,10]$.The commonly accepted cause is abscess formation after obstruction of anal gland ducts and epithelialization of the tract after opening of the abscess to the skin $[2-4,11]$. The incidence of anal fistula as a common disease in European countries is reported to be between 1.04 and 2.32 per 10,000/year [12]. Fistula disease can be a source of stress for the patient and the surgeon, although diagnosis and treatment are often simple. For the correct treatment of the anal fistula, it is necessary to know the etiology of the disease and its relation to sphincter muscles. 
Table 2: Comparison of the imaging techniques on the variables of the study group according to presence or absence of each technique.

\begin{tabular}{|c|c|c|c|c|c|c|c|c|c|c|}
\hline & All, $n=307$ & Endoscopy & $\begin{array}{l}\text { Endoscopy } \\
\text { absent }\end{array}$ & $\mathrm{p}$ & MR & MR absent & $\mathrm{p}$ & $\begin{array}{c}\text { Endoscopy } \\
\text { and MR }\end{array}$ & $\begin{array}{c}\text { Endoscopy and MR } \\
\text { absent }\end{array}$ & $\mathrm{p}$ \\
\hline & $\mathrm{n}(\%)$ & $83(27)$ & $224(73)$ & $\mathrm{n} / \mathrm{a}$ & $162(53)$ & $145(47)$ & $\mathrm{n} / \mathrm{a}$ & 60 & 247 & $\mathrm{n} / \mathrm{a}$ \\
\hline $\begin{array}{l}\text { Age } \\
\text { Gender }\end{array}$ & $40.6 \pm 11.2$ & $41.1 \pm 11.3$ & $40.4 \pm 11.2$ & 0.637 & $39.5 \pm 11.5$ & $41.7 \pm 10.8$ & 0.880 & $40.6 \pm 11.8$ & $40.6 \pm 11.1$ & 0.971 \\
\hline Male & $246(80)$ & $65(26.4)$ & $181(73.6)$ & 0.368 & $128(52)$ & $118(48)$ & 0.668 & $48(20)$ & $198(80)$ & 1.000 \\
\hline $\begin{array}{l}\text { Female } \\
\text { Fistula type } n,(\%)\end{array}$ & $61(20)$ & $18(29.5)$ & $43(70.5)$ & & $34(56)$ & $27(44)$ & & $12(20)$ & $49(80)$ & \\
\hline $\begin{array}{l}\text { Simple } \\
\text { Complicated } \\
\text { Seton requirement }\end{array}$ & $\begin{array}{c}239(78) \\
68(22)\end{array}$ & $\begin{array}{l}60(25.1) \\
23(33.8)\end{array}$ & $\begin{array}{l}179(74.9) \\
45(66.2)\end{array}$ & 0.103 & $\begin{array}{l}120(50) \\
42(62)\end{array}$ & $\begin{array}{l}119(50) \\
26(38)\end{array}$ & 0.100 & $\begin{array}{l}41(28) \\
19(28)\end{array}$ & $\begin{array}{l}198(72) \\
49(72)\end{array}$ & 0.057 \\
\hline $\begin{array}{l}\text { Yes } \\
\text { No }\end{array}$ & $\begin{array}{c}32(10) \\
275(90)\end{array}$ & $\begin{array}{c}8(25.0) \\
75(27.3)\end{array}$ & $\begin{array}{c}24(75.0) \\
200(72.7)\end{array}$ & 0.485 & $\begin{array}{c}26(81) \\
136(49)\end{array}$ & $\begin{array}{c}6(19) \\
139(51)\end{array}$ & 0.001 & $\begin{array}{r}8(25) \\
52(19)\end{array}$ & $\begin{array}{c}24(75) \\
223(81)\end{array}$ & 0.479 \\
\hline
\end{tabular}

According to the relationship with sphincters, fistulas are classified as superficial, intersphincteric, transsphincteric, suprasphincteric and extrasphincteric. Intersphincteric and transsphincteric fistula constitute the majority of the fistula $[6$, 13]. Anal fistulas are also classified as simple or complicated $[14,15]$. Complicated anal fistulas include transsphincteric fistulas containing $30 \%$ of the external sphincter, suprasphincteric, extrasphincteric, horseshoe fistulas, inflammatory bowel disease-related fistulas, fistulas caused by radiation damage, anteriorly located fistulas in women, malignancy-associated fistulas [4].

Since the surgeons know the difficulties of fistula surgery, they make the necessary examinations to understand the type of the fistula in the preoperative period. Sometimes this can result in excessive use of available facilities. Occasionally, history and physical examination may reveal whether the fistula is a simple or complicated fistula, but the doubt of secondary tracts leads to the desire for additional tests for diseases such as Crohn's disease and rectum cancer. MRI is considered to be the most useful method in evaluating the relationship between the fistula and the sphincter complex [5, 16]. While useful for recurrent and complicated fistulas, the contribution is fairly small for simple fistulas.

We could not find a study in the literature about the use of colonoscopy and FRS in fistula operations. There have been many studies on the use and indications of colonoscopy, most of them related to malignancy scans and inflammatory bowel disease. Fistula-related articles rarely mention this topic referring that it is used routinely in some clinics and only for inflammatory bowel disease and malignancy suspicion in some others.

In this study we evaluated the impact of preoperative diagnostic techniques i.e. endoscopy and MRI on the type and treatment of perianal fistula. Many studies had already mentioned about the importance of preoperative MRI on the treatment of anal fistula [16]. In our study the patients who were treated with a seton placement had more MRI preoperatively than non-seton placed patients significantly. This result may reflect that seton placed fistulas are mostly associated with external sphincter and may be considered as complex fistula. Also more MRI application in this group might have directed the surgeon for seton placement. The patients who were performed both MRI and endoscopy did not show any significance in fistula type and seton placement. We may attribute this to the retrospective nature of the study and to the preoperative diagnostic modalities being surgeon-dependent and nonhomogeneous. In this study, $27 \%$ of patients who underwent surgery for fistula received endoscopy. These data are based on hospital records. The rate may be lower than the actual value, because the patients who had endoscopy in another hospital couldn't be evaluated. We estimate that FRS or colonoscopy has been done to over $50 \%$ of the patients. This issue can be recognized as the limitation of the study, it has to be revealed with prospectively designed new studies.
In our study, inner orifice of fistula was seen in only one patient's endoscopy. Therefore endoscopy may be considered to be ineffective in determining the fistula tract or the internal orifice. The inner orifice of simple fistulas is usually at the level of anal crypts, and the sight of the inner orifice with a flexible colonoscope is almost impossible. Examination with rigid rectoscope / proctoscope is recommended in the literature for inner orifice evaluation. None of the patients had evidence of a malignancy with endoscopy and the most common finding was diminutive benign polyps. The detection rate of polyps was also the same as the normal population [17].

In the prospective study performed by Buchanan and colleagues comparing with physical examination, endoanal ultrasonography and MRI; MRI was found to be the most effective method in determining the secondary fistula tracts and fistula internal orifices. They reported that all patients went through FRS, but no FRS results were reported [5].We can understand from the literature that anamnesis, physical examination, MRI, and examination under anesthesia can be sufficient for determining the treatment of a fistula patient.

One of the limitations of this research study was the constitution of the sample. First, patients were not randomly selected from a larger population to participate in the study, because of the retrospective design. This might be considered as a bias. The results might not generalize to other populations, particularly those with greater diversity in ethnicity and social class in respect to disease distribution.

In conclusion, our suggestion with this study's findings for the impact of preoperative diagnostic techniques on the type and treatment of perianal fistula is as follows; preoperative categorization and decision of treatment modality for anal fistula should not be generalized. Depending on the patient; physical examination, radiological examination, and endoscopic examination should be performed alone or together. Additionally, performing MRI preoperatively may help the surgeon for decision of seton placement.

\section{References}

1. Malik AI, Nelson RL. Surgical management of anal fistula: a systematic review. Colorectal Disease. 2008;10:420-30.

2. Parks AG. Pathogenesis and treatment of fistula-in-ano. Br Med J. $1961 ; 18: 1$.

3. Gosselink MP, van Onkelen RS, Schouten WR. The cryptoglandular theory revisited. Colorectal Dis. 2015;17:1041-3.

4. Jon D. Vogel, Eric K. Johnson. Clinical Practice Guideline for the Managementof Anorectal Abscess, Fistula-in-Ano, and Rectovaginal Fistula. Dis Colon Rectum. 2016;59:1117-33.

5. Buchanan GN, Halligan S, Bartram CI, Williams AB, Tarroni D, Cohen CR. Clinical examination, endosonography, and MR imaging in preoperative assessment of fistula in ano: comparison with outcomebased reference standard. Radiology. 2004;233:674-81.

6. Gültekin FA, Çipe G, Sümer D, Sücüllü İ, Sungurtekin U, Bugra D. Anal Fistül Cerrah Tutum Anketi 2013, Sonuç Rapor. Kolon Rektum Hast Derg. 2013;23:81-8.

7. Juillerat $P$, Peytremann-Bridevaux I, Vader JP, Arditi C, SchusseléFilliettaz S, Dubois RW, et al. Appropriateness of colonoscopy in Europe (EPAGE II). Presentation of methodology, 
general results, and analysis of complications. Endoscopy. 2009;41:2406.

8. Kok L, Elias SG, Witteman BJ, Goedhard JG, Romberg-Camps MJ, Muris JW, Moons KG, de Wit NJ. Application of the Rome III criteria is not likely to reduce the number of unnecessary referrals for colonoscopy in primary care. Eur J Gastroenterol Hepatol. 2013;25:568-74.

9. Arditi C, Peytremann-Bridevaux I, Burnand B, Eckardt VF, Bytzer P, Agréus L, et al. Appropriateness of colonoscopy in Europe (EPAGE II). Screening for colorectal cancer. Endoscopy. 2009;41:200-8.

10. Kiehne K, Fincke A, Brunke G, Lange T, Fölsch UR, Herzig KH. Antimicrobial peptides in chronic anal fistula epithelium. Scand J Gastroenterol. 2007;42:1063-9.

11. Abcarian H. Anorectal infection: Abscess-Fistula. Clin Colon Rectal Surg. 2011;24:14-21.

12. Zanotti C, Martinez-Puente C, Pascual I, Pascual M, Herreros D, García-Olmo D. An assessment of the incidence of fistula-in-ano in four countries of the European Union. Int J Colorectal Dis. 2007; 22:14591462.

13. Hall JF, Bordeianou L, Hyman N, Read T, Bartus C, Schoetz D, et al. Outcomes after operationsfor anal fistula: results of a prospective, multicenter, regional study. Dis Colon Rectum. 2014;57:1304-8.

14. Parks AG, Gordon PH, Hardcastle JD. A classification of fistula in- ano. Br J Surg. 1976; 63:1-12.

15. Beets-Tan RG1, Beets GL, van der Hoop AG, Kessels AG, Vliegen RF, Baeten CG, et al. Preoperative MR imaging of anal fistulas: Does it really help the surgeon? Radiology. 2001;218:75-84.

16. Sivri M, Koplay M, Nayman A, Cebeci H, Güler İ, Uysal E, Paksoy Y. Perianal fistülün tanısında, sınıflandırılmasında ve değerlendirilmesinde Manyetik Rezonans Görüntüleme'nin önemi. Arch Clin Exp Med. 2017; 2:1-5.

17. Giacosa A, Frascio F, Munizzi F. Epidemiology of colorectal polyps. Techniques in Coloproctology 2004;8:243-7.

18. Göktürk S, Karaca C. İnflamatuar Barsak Hastalıkları Epidemiyolojisi. Turkiye Klinikleri J Gastroenterohepatol Special Topics. 2012;5:11-6.

19. Yamada K, Miyakura Y, Koinuma K, Horie H, Lefor AT, Yasuda Y. Primary and secondary adenocarcinomas associated with anal fistula. Surg Today. 2014;44:888-96.

20. Yu D, Hopman WM, Paterson WG. Wait time for endoscopic evaluation at a Canadian tertiary care centre: comparison with Canadian Association of Gastroenterology targets. Can J Gastroenterol. 2008;22:621-6. 